\title{
Anticancer activity, DNA binding and cell mechanistic studies of estrogen-functionalised $\mathrm{Cu}(\mathrm{II})$ complexes
}

\author{
Stephen Barrett ${ }^{1} \cdot$ Michele De Franco $^{2} \cdot$ Andrew Kellett $^{3} \cdot$ Eithne Dempsey $^{1} \cdot$ Cristina Marzano $^{2} \cdot$ Andrea Erxleben $^{4}$. \\ Valentina Gandin ${ }^{2} \cdot$ Diego Montagner $^{1}$ (i)
}

Received: 8 August 2019 / Accepted: 8 October 2019 / Published online: 26 October 2019

(c) Society for Biological Inorganic Chemistry (SBIC) 2019

\begin{abstract}
Four estrogen-functionalised copper complexes were synthesised and investigated as electrochemical active DNA binding and cleavage agents. These complexes strategically contain a biocompatible metal centre [Cu(II)], a planar aromatic ligand as DNA intercalative agent and an estradiol-derivative moiety which acts as delivery vector to target estrogen-receptor-positive $(\mathrm{ER}+)$ cancer cells. Cytotoxic activity was studied over a panel of estrogen-receptor-positive (ER+) and negative (ER-) human cancer cell lines by means of both 2D and 3D cell viability studies. The complexes showed high in vitro intercalative interaction with nuclear DNA and demonstrated to be strong DNA cleaving agents. This series of Cu compounds are potent anticancer agents with low and sub-micromolar $\mathrm{IC}_{50}$ values and the cellular uptake follows the lipophilicity order meaning that the internalisation mainly happened via passive diffusion. Finally, the estrogen-complexes are involved in the cellular redox stress by stimulating the production of ROS (reactive oxygen species).
\end{abstract}

\section{Graphic abstract}

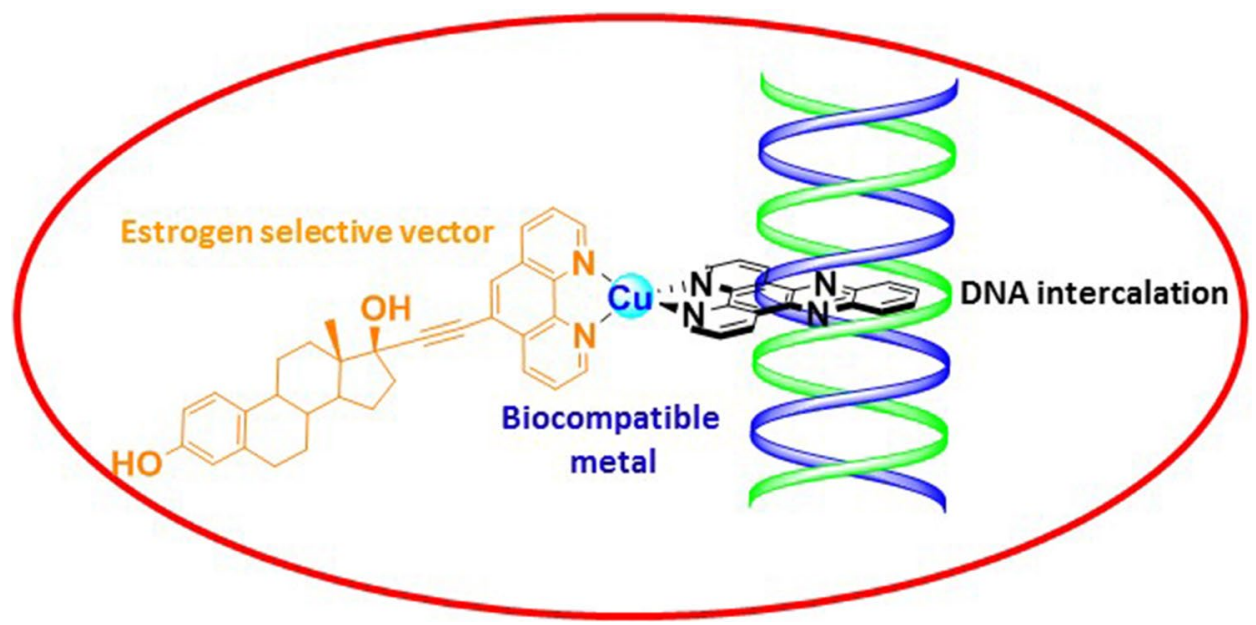

Keywords Copper $\cdot$ Anticancer drug $\cdot$ DNA intercalation $\cdot$ ROS production $\cdot$ Estrogen $\cdot$ Selective target

Electronic supplementary material The online version of this article (https://doi.org/10.1007/s00775-019-01732-8) contains supplementary material, which is available to authorized users.

Valentina Gandin

valentina.gandin@unipd.it

$\triangle$ Diego Montagner diego.montagner@mu.ie

Extended author information available on the last page of the article

\section{Introduction}

Copper complexes are becoming interesting developmental anticancer agents and many recent examples demonstrated the efficacy of tumour treatment with $\mathrm{Cu}$-containing drugs $[1,2]$. Copper complexes are considered as an alternative 
to the classical platinum containing anticancer drugs (i.e., cisplatin, carboplatin, oxaliplatin) because copper, being an endogenous essential metal for most aerobic organisms, is better tolerated compared to exogenous metals. In addition, the altered copper metabolism displayed by many cancer cells as well as the differential response between normal and tumour cells to copper, laid down the rationale for the development of copper complexes as anticancer agents. Casiopeinas is the generic name of a group of copper complexes designed to be used as antineoplastics and have recently shown promising results as chemotherapeutic agents in animal models and clinical trials [3, 4]. Copper is involved in fundamental biological processes such as respiration, detoxification of ROS (reactive oxygen species) and copper-based drugs show a wide spectrum of action [5-12]. Copper is a biological redox active metal centre $\left(\mathrm{Cu}^{2+}+1 \mathrm{e}^{-} \rightarrow \mathrm{Cu}^{+}\right.$ $\left.E_{0}=0.153 \mathrm{~V}\right)$ and it is involved in the regulation of ROS $\left(\mathrm{OH}, \mathrm{O}^{2-} \ldots\right)$ via Fenton and Haber-Weiss type reactions that are responsible for the cleavage of the DNA back-bonds [13-20]. Copper plays a major role in cancer cell oxidative stress that can result in detrimental cellular damage including lipid peroxidation, DNA damage, protein oxidation and enzyme inactivation, which in turn can lead to cell death. One of the pioneer examples of anticancer $\mathrm{Cu}$ (II) complexes is $\left[\mathrm{Cu}(\text { phen })_{2}\right]^{2+}$ (phen $=1,10$-phenanthroline) reported by Sigman and co-workers, that showed a strong anticancer and nuclease activity in the presence of reducing agents $[21,22]$. This compound also showed a strong interaction with DNA and it was able to intercalate between the DNA nucleobases due to the presence of the planar aromatic phenanthroline ligand. $\left[\mathrm{Cu}(\mathrm{phen})_{2}\right]^{2+}$ opened the route to the synthesis of several metal complexes with DNA intercalative properties using modified phenanthroline ligands such as DPQ, DPPZ and DPPN (DPQ = dipyrido[3,2-f:2', $\left.3^{\prime}-h\right]$ quinoxaline, DPPZ $=$ dipyrido $\left[3,2-a: 2^{\prime}, 3^{\prime}-c\right]$ phenazine, and DPPN $=$ benzo[i]dipyrido[3,2-a:2', $\left.3^{\prime}-c\right]$ phenazine) [23-30]. These complexes showed great DNA binding affinity and anticancer properties but negligible selectivity for tumour tissues. One of the most desired properties for an anticancer drug is the selectivity for cancer cells and, furthermore, for some specific cancer tissues. Steroids are important delivery vectors that can be used for the selective targeting of the drugs toward the cancer cell [31]. The activity of estrogens, the primary female sex hormone, is mediated by the presence of estrogen receptors (ERs) in cells and ERs are over-expressed in breast, ovarian, colon and prostate cancers, which are termed ER+[32, 33]. ERs therefore, represent interesting anticancer targets [34, 35]. Several cancers are estrogen-dependent (i.e., ovarian cancer) and estrogen derivatives are also used in the treatment of particular cancers. In turn, a host of strategies have been employed to date where derivatives of one of the three major endogenous estrogens (estrone, estradiol, and estriol) have been chemically linked to a platinum-containing anticancer drug [36-38] and radiopharmaceuticals [39]. Recently, we reported the antimicrobial and anticancer activity of steroid derivatives of $\mathrm{Cu}(\mathrm{II}), \mathrm{Pt}(\mathrm{II})$, and $\mathrm{Au}(\mathrm{I})$ complexes containing both the female (estradiol) and male (testosterone) steroids [40-42]. Here, we present the syntheses, chemical and electrochemical investigation, the DNA binding and cleavage properties together with a detailed biological study of the anticancer activity on 2D and 3D cancer cell cultures of a series of estrogen-functionalized $\mathrm{Cu}$ (II) complexes with the general formula $[\mathrm{Cu}(\mathrm{N} \cap \mathrm{N})($ estradiol-phen $)]\left(\mathrm{NO}_{3}\right)_{2}$, where $(\mathrm{N} \cap \mathrm{N})$ is phenanthroline, DPQ, DPPZ and DPPN (Fig. 1). Some of these complexes, which display the simultaneous presence of both the non-toxic metal centre [copper(II)] and of a planar ligand for DNA intercalation properties
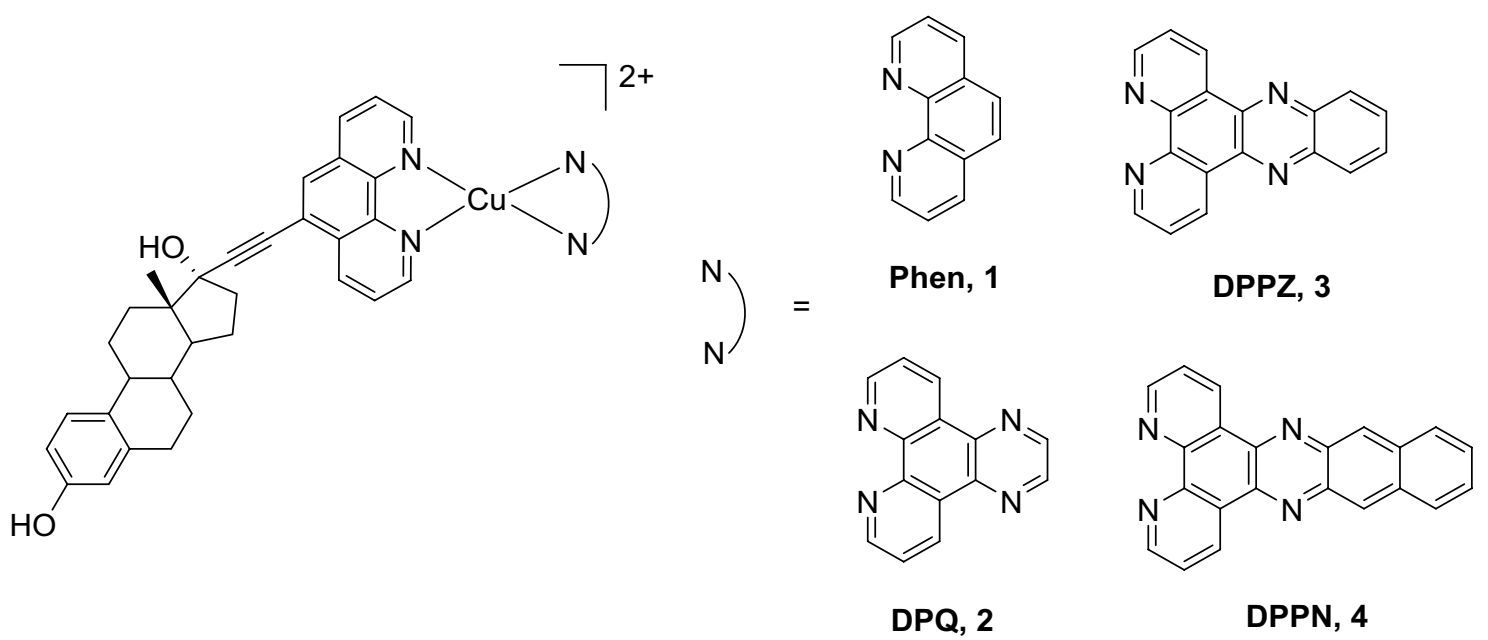

Fig. 1 Structures of the estrogen-derivatives $\mathrm{Cu}$ (II) complexes 
(Phen, DPQ, DPPZ and DPPN), along with the presence of an estrogen-derivative as a delivery vector to target cancer cells, showed important in vitro and in vivo antimicrobial activity against Staphylococcus aureus [41]. The biological activity is assessed using cancer cell lines expressing estrogen receptors $(\mathrm{ER}+)$ and not expressing estrogen receptors (ER-) with the aim of verifying the successfulness of copper functionalization.

\section{Materials and methods}

All reagents and reactants were purchased from commercial sources. The two sources used were Sigma-Aldrich and Tokyo Chemical Industry. All solvents were used without further purification. The THF (Tetrahydrofuran) used for the Sonogashira coupling reaction, was dried using four angstrom molecular sieves, it was then decanted into a round bottom flask and kept under high vacuum using a Schlenk line while immersed in liquid nitrogen. The THF was then flushed with nitrogen gas. This step was repeated a minimum of three times for the Sonogashira coupling reaction. All NMR spectra were recorded on a Bruker Advance spectrometer with the probe at $293 \mathrm{~K}$, operating at $500 \mathrm{MHz}$ for the ${ }^{1} \mathrm{H}$ and at $125 \mathrm{MHz}$ for ${ }^{13} \mathrm{C}\left\{{ }^{1} \mathrm{H}\right\}$ nuclei. Spectra were recorded in $\mathrm{CDCl}_{3}$ using $\mathrm{Me}_{4} \mathrm{Si}$ as the internal standard. All chemical shifts are in ppm. Infrared (IR) spectra were recorded in the region $4000-400 \mathrm{~cm}^{-1}$ on a Perkin Elmer precisely spectrum 100 FT/IR spectrometer. The solid samples were run using ATR. Elemental analyses (carbon, hydrogen and nitrogen) were performed with a PerkinElmer 2400 series II analyzer. ESI mass spectra were recorded in positive mode with a Waters LCT Premier XE Spectrometer.

Electrochemistry: Non-aqueous electrochemical analysis of $1 \mathrm{mM}$ of the copper complexes 1-3 was carried out at a glassy carbon electrode $\left(0.07 \mathrm{~cm}^{2}\right)$ in a three electrode configuration with $\mathrm{Pt}$ wire counter and non-aqueous reference $\mathrm{Ag} / \mathrm{Ag}^{+}$reference electrode in $0.1 \mathrm{M} \mathrm{LiClO}_{4} / \mathrm{DMF}$ (dimethylformamide). Glassy carbon electrodes were prepared by polishing with alumina suspension on a microcloth followed by sonication in deionised water. Voltammograms were generated over the range +1 to -1 or $-2 \mathrm{~V}$ vs. $\mathrm{Ag} /$ $\mathrm{Ag}^{+}$in a deaerated solution ( $\mathrm{N}_{2}$ bubbling $10 \mathrm{~min}$ ). Data analysis employed the third cycle of the voltammogram with cathodic scan direction at $100 \mathrm{mV} \mathrm{s}^{-1}$ in all cases.

Stability: Compound $\mathbf{4}$ was taken as reference being the most active. 4 was dissolved in DMF to obtain a $5 \mathrm{mM}$ solution. $200 \mu \mathrm{L}$ of this solution was diluted to $2.0 \mathrm{~mL}$ with phosphate buffer solution $(\mathrm{pH}=7.4,[P]=50 \mathrm{mM})$. The solution was kept at $37{ }^{\circ} \mathrm{C}$ and monitored by HPLC using a Phenomenex Luna C18 (5 $\mu \mathrm{M}, 100 \AA$ A, $250 \mathrm{~mm} \times 4.60 \mathrm{~mm}$ i.d.) column at a flow rate of $1.0 \mathrm{~mL} / \mathrm{min}$ with $280 \mathrm{~nm} \mathrm{UV}$ detection at room temperature. The mobile phase was 80:20 acetonitrile $(0.1 \%$ trifluoroacetic acid): water $(0.1 \%$ trifluoroacetic acid).

\section{DNA binding experiments}

\section{Competitive ethidium displacement}

A working solution of $20.0 \mu \mathrm{M}$ UltraPure calf-thymus DNA [CT-DNA, Invitrogen 15633-019, $\varepsilon 260=12,824 \mathrm{M}$ (bp) $)^{-1} \mathrm{~cm}^{-1}$ ] along with $25.2 \mu \mathrm{M}$ ethidium bromide $(\mathrm{EtBr})$ in HEPES buffer $(80 \mathrm{mM}, \mathrm{pH}=7.2)$ and $\mathrm{NaCl}(40 \mathrm{mM})$ was prepared. Stock solutions of metal complexes, metal salts, and groove binding drugs were prepared at $\sim 4.0 \mathrm{mM}$ in DMSO (dimethylsulfoxide) and diluted further with ultra-pure water. $50 \mu \mathrm{L}$ of DNA-Et working solution was placed in each well of a 96-well microplate with the exception of the blanks which contained $100 \mu \mathrm{L}$ HEPES buffer. Serial aliquots of the tested compound were added to the working solutions and the volume was adjusted to $100 \mu \mathrm{L}$ in each well such that the final concentration of CT-DNA and $\mathrm{EtBr}$ was $10.0 \mu \mathrm{M}$ and $12.6 \mu \mathrm{M}$, respectively. The plate was allowed to incubate at room temperature for $1 \mathrm{~h}$ before being analyzed using a Bio-Tek synergy HT multi-mode microplate reader with excitation and emission wavelengths being set to 530 and $590 \mathrm{~nm}$, respectively. Concentrations of the tested compounds were optimized such that fluorescence was $30-40 \%$ of the initial control (i.e., $50 \mu \mathrm{L}$ working solution $+50 \mu \mathrm{L}$ HEPES buffer) at their highest reading. Each drug concentration was measured in triplicate, on at least two separate occasions, and the apparent binding constants were calculated using $K_{\text {app }}=K_{\mathrm{e}} \times 12.6 / \mathrm{C} 50$ where $K_{\mathrm{e}}=9.5 \times 10^{6} \mathrm{M}(\mathrm{bp})^{-1}$.

\section{DNA-ethidium fluorescence quenching}

A working solution of $50.0 \mu \mathrm{M}$ UltraPure calf-thymus DNA [CT-DNA, Invitrogen $15633019, \varepsilon 260=12,824 \mathrm{M}$ $(\mathrm{bp})^{-1} \mathrm{~cm}^{-1}$ ] along with either $10.0 \mu \mathrm{M}$ ethidium bromide (EtBr) or Hoechst 33258 (Sigma) in HEPES buffer $(80 \mathrm{mM}$, $\mathrm{pH}=7.2)$ and $\mathrm{NaCl}(40 \mathrm{mM})$ was prepared. Stock solutions of metal complexes, metal salts, free ligands and groove binding drugs were prepared at $\sim 4.0 \mathrm{mM}$ in DMSO and diluted further with ultra-pure water. $50 \mu \mathrm{L}$ of DNA-Et or DNA-Hoechst working solution were placed in each well of a 96-well microplate with the exception of the blanks which contained $100 \mu \mathrm{L}$ HEPES buffer and $5 \mu \mathrm{M}$ of either Hoechst or EtBr. Serial aliquots of the tested compound were added to the working solutions and the volume was adjusted to $100 \mu \mathrm{L}$ in each well such that the final concentrations of CT-DNA and EtBr/Hoechst were $25.0 \mu \mathrm{M}$ and $5 \mu \mathrm{M}$, respectively. The plate was allowed to incubate at room temperature for $5 \mathrm{~min}$ before being analyzed using a Bio-Tek synergy HT multi-mode microplate reader with 
excitation and emission wavelengths being set to 530 and $590 \mathrm{~nm}$ for Et detection or $360 \mathrm{~nm}$ and $460 \mathrm{~nm}$ for Hoechst 33258 detection. Concentrations of the tested compounds were optimized such that fluorescence was $30-40 \%$ of the initial control at their highest reading. Each drug concentration was measured in triplicate, on at least two separate occasions. From a plot of fluorescence versus added drug concentration, the $Q$ value is given by the concentration required to effect $50 \%$ removal of the initial fluorescence of bound dye.

\section{Viscosity experiments}

Fifteen mL dsDNA (deoxyribonucleic acid sodium salt from Salmon Testes, Sigma-Aldrich, D1626-1G) solution was prepared at $1 \times 10^{-3} \mathrm{M}$ in $80 \mathrm{mM}$ HEPES buffer for each working sample.

Stock solutions prepared in DMSO were added according to the gradual increasing [drug]/[DNA] $(r)$ ratios of 0.025 , $0.05,0.075,0.1,0.125,0.15,0.175$ and 0.2 . Viscosity values, $\eta$, (unit: $\mathrm{CP}$ ) were directly obtained by running $0 \#$ spindle in working samples at $60 \mathrm{rpm}$ via DV-II-programmable digital viscometer equipped with enhanced brookfield UL Adapter at room temperature. Data were presented as $\eta / \eta_{\mathrm{o}}$ versus [compound]/[DNA] ratio, in which $\eta_{\mathrm{o}}$ and $\eta$ refers to viscosity of each DNA working sample in the absence and presence of complex.

\section{Nuclease activity}

Reactions were carried according to the literature procedure [29]. Briefly, in a total volume of $20 \mu \mathrm{L}$ using $80 \mathrm{~mL}$ of HEPES buffer (Fisher) at pH 7.2 with $25 \mathrm{mM} \mathrm{NaCl}$, an aliquot of the stock complex (prepared in DMSO) was mixed with $400 \mathrm{ng}$ of pUC19 (Roche) and $1 \mu \mathrm{L}$ of $20 \mathrm{mM}$ Na-L-ascorbate. Samples were incubated at $37^{\circ} \mathrm{C}$ for $3 \mathrm{~h}$ before being quenched with $6 \times$ loading dye (Fermentas), containing $10 \mathrm{mM}$ Tris- $\mathrm{HCl}(\mathrm{pH}$ 7.6), $0.03 \%$ bromophenol blue, $0.03 \%$ xylene cyanol, $60 \%$ glycerol and $60 \mathrm{mM}$ EDTA, then loaded onto agarose gel $1 \%$ containing $2.0 \mu \mathrm{L}$ of GelRedTM (10000×). Electrophoresis was completed at $80 \mathrm{~V}$ for $1.5 \mathrm{~h}$ using a wide mini-sub cell (Bio-Rad) in 1XTAE buffer (Millipore).

\section{Biological studies}

Copper complexes 1-4 were dissolved in the minimum DMSO amount prior to cell culture testing. A calculated amount of the stock drug DMSO solution was added to the cell culture media to reach a final maximum DMSO concentration of $0.5 \%$, which had no effects on cell viability. Cisplatin was dissolved in $0.9 \%$ sodium chloride solution. MTT [3-(4,5-dimethylthiazol-2-yl)- 2,5-diphenyltetrazolium bromide], cisplatin and ImmunoPure $p$-nitrophenyl phosphate (APH) were obtained from Sigma Chemical Co, St. Louis, USA.

\section{Cell cultures}

Human colon (HCT-15) and breast (MCF-7) carcinoma cell lines were obtained from American Type Culture Collection (ATCC, Rockville, MD). Human ovarian 2008 cancer cells were kindly provided by Prof. G. Marverti (Dept. of Biomedical Science of Modena University, Italy). Human ovarian A2780 cancer cells were kindly provided by Prof. M.P.Rigobello (Dept. of Biomedical Science of Padova University, Italy). Human squamous cervical A431 carcinoma cells were kindly provided by Prof. F. Zunino (Division of Experimental Oncology B, Istituto Nazionale dei Tumori, Milan, Italy). Cell lines were maintained in the logarithmic phase at $37{ }^{\circ} \mathrm{C}$ in a $5 \%$ carbon dioxide atmosphere using RPMI-1640 medium (Euroclone) containing $10 \%$ foetal calf serum (Euroclone, Milan, Italy), antibiotics (50 units $\mathrm{mL}^{-1}$ penicillin and $50 \mu \mathrm{g} \mathrm{mL}^{-1}$ streptomycin), and $2 \mathrm{mM}$ L-glutamine.

\section{Spheroid cultures}

Spheroids were initiated in liquid overlay by seeding $1.5 \times 10^{3}$ A2780 or HCT-15 cells/well in phenol red free RPMI-1640 medium (Sigma Chemical Co.), containing $10 \%$ FCS and supplemented with $20 \%$ methyl cellulose stock solution. A total of $150 \mu \mathrm{L}$ of this cell suspension was transferred to each well of a round bottom non-tissue culture treated 96-well plate (Greiner Bio-one, Kremsmünster, Austria) to allow spheroid formation within $72 \mathrm{~h}$.

\section{Cytotoxicity assays}

\section{MTT assay}

The growth inhibitory effect towards adherent cancer cell lines was evaluated by means of MTT assay. Briefly, $3-8 \times 10^{3}$ cells/well, dependent upon the growth characteristics of the cell line, were seeded in 96-well microplates in growth medium $(100 \mu \mathrm{L})$. After $24 \mathrm{~h}$, the medium was removed and replaced with fresh media containing the compound to be studied at the appropriate concentration. Triplicate cultures were established for each treatment. After $72 \mathrm{~h}$, each well was treated with $10 \mu \mathrm{L}$ of a $5 \mathrm{mg} \mathrm{mL}^{-1}$ MTT saline solution, and after additional $5 \mathrm{~h}$ of incubation, $100 \mu \mathrm{L}$ of a sodium dodecylsulfate (SDS) solution in $\mathrm{HCl}$ $0.01 \mathrm{M}$ were added. Following an overnight incubation, cell growth inhibition was detected by measuring the absorbance of each well at $570 \mathrm{~nm}$ using a Bio-Rad 680 microplate reader. Mean absorbance for each drug dose was expressed 
as a percentage of the absorbance of the untreated control well and plotted vs drug concentration. $\mathrm{IC}_{50}$ values, the drug concentrations that reduce the mean absorbance at $570 \mathrm{~nm}$ to $50 \%$ of those in the untreated control wells, were calculated by four parameters logistic (4-PL) model. All the values are the means \pm SD of not less than five measurements starting from three different cell cultures.

\section{Acid phosphatase (APH) assay}

An APH-modified assay was used for determining cell viability in 3D spheroids. Briefly, the pre-seeded spheroids were treated with fresh medium containing the compound to be studied at the appropriate concentration. Triplicate cultures were established for each treatment. After $72 \mathrm{~h}$, each well was treated with $100 \mu \mathrm{L}$ of the assay buffer $(0.1 \mathrm{M}$ sodium acetate, $0.1 \%$ Triton-X-100, supplemented with ImmunoPure $p$-nitrophenyl phosphate) and, following $3 \mathrm{~h}$ of incubation, $10 \mu \mathrm{L}$ of $1 \mathrm{M} \mathrm{NaOH}$ solution was added. The inhibition of the cell growth induced by the tested complexes was detected by measuring the absorbance of each well at $405 \mathrm{~nm}$, using a Bio-Rad 680 microplate reader. Mean absorbance for each drug dose was expressed as a percentage of the untreated control well absorbance (T/C) and plotted vs drug concentration. $\mathrm{IC}_{50}$ values, the drug concentrations that reduce the mean absorbance at $405 \mathrm{~nm} \mathrm{50 \%}$ of those in the untreated control wells, were calculated by four parameter logistic (4-PL) model. Evaluation was based on means from at least four independent experiments.

\section{Cellular uptake and DNA binding}

A2780 and HCT-15 cells $\left(3 \times 10^{6}\right)$ were seeded in $75 \mathrm{~cm}^{2}$ flasks in growth medium $(20 \mathrm{~mL})$. After overnight incubation, the medium was replaced and the cells were treated with tested compounds for $24 \mathrm{~h}$. Cell monolayers were washed twice with cold PBS, harvested and counted. Samples were than subjected to three freezing/thawing cycles at $-80{ }^{\circ} \mathrm{C}$, and then vigorously vortexed. The samples were treated with highly pure nitric acid $\left(\mathrm{Cu}: \leq 0.5 \mu \mathrm{g} \mathrm{kg}^{-1}\right.$, TraceSELECT ${ }^{\circledR}$ Ultra, Sigma Chemical Co.) and transferred into a microwave Teflon vessel. Subsequently, samples were submitted to standard procedures using a speed wave MWS-3 Berghof instrument (Eningen, Germany). After cooling, each mineralized sample was analyzed for platinum using a Varian AA Duo graphite furnace atomic absorption spectrometer (Varian, Palo Alto, CA; USA) at the wavelength of $324 \mathrm{~nm}$. The calibration curve was obtained using known concentrations of standard solutions purchased from Sigma Chemical Co. purchased from Sigma Chemical Co.

For DNA binding studies, DNA was extracted and purified by a commercial spin column quantification kit (Qiagen DNeasy Blood and Tissue Kit). Only highly purified samples (A260/A230·1.8 and A280/A260·2.0) were included for analysis to avoid any artefacts. The samples were completely dried and re-dissolved in $200 \mu \mathrm{L}$ of Milli-Q water $\left(18.2 \mathrm{M} \Omega\right.$ ) for at least $20 \mathrm{~min}$ at $65^{\circ} \mathrm{C}$ in a shaking thermomixer, mineralized and analyzed for total $\mathrm{Cu}$ content by GFAAS as described above.

\section{Reactive oxygen species (ROS) production}

The production of ROS was measured in A2780 cells $\left(10^{4}\right.$ per well) grown for $24 \mathrm{~h}$ in a 96 -well plate in RPMI medium without phenol red (Sigma Chemical Co.). Cells were then washed with PBS and loaded with $10 \mu \mathrm{M} 5$-(and6)-chloromethyl-2', 7'-dichlorodihydrofluorescein diacetate acetyl ester (CM- $\mathrm{H}_{2}$ DCFDA) (Molecular Probes-Invitrogen, Eugene, OR) for $25 \mathrm{~min}$, in the dark. Afterwards, cells were washed with PBS and incubated with tested compounds. Fluorescence increase was estimated utilizing the wavelengths of $485 \mathrm{~nm}$ (excitation) and $527 \mathrm{~nm}$ (emission) in a Fluoroskan Ascent FL (Labsystem, Finland) plate reader. Antimycin $(3 \mu \mathrm{M}$, Sigma Chemical Co), a potent inhibitor of Complex III in the electron transport chain, was used as positive control.

\section{Comet assay}

About $4 \times 104$ A2780 cells were seeded in $25 \mathrm{~cm}^{2}$ flasks in growth medium $(6 \mathrm{~mL})$. After $24 \mathrm{~h}$, cells were incubated for $3 \mathrm{~h}$ with $2.5 \mu \mathrm{M}$ of tested compounds. Cells were washed twice with cold PBS, harvested, centrifuged, and DNA fragmentation was measured by the alkaline comet assay. Low melting point agarose, $300 \mu \mathrm{L}$ (Trevigen Inc., Gaithersburg, MD, US) was heated to $37{ }^{\circ} \mathrm{C}$ and combined with $2 \times 10^{5}$ cells per $\mathrm{mL}$ cell suspension. Each well of a 20-well CometSlide was filled with $30 \mu \mathrm{L}$ of the cell/agarose suspension. The slides were placed in a $4{ }^{\circ} \mathrm{C}$ refrigerator in the dark for $15 \mathrm{~min}$ to solidify. Slides were then immersed in $50 \mathrm{~mL}$ of pre-chilled lysis solution containing Trizma base, Triton-X-100, DMSO and left at $4{ }^{\circ} \mathrm{C}$ for $30 \mathrm{~min}$ to facilitate cell membrane and histone removal. After draining excess liquid, the slides were transferred to $50 \mathrm{~mL}$ of freshly prepared (same day) alkaline DNA unwinding solution, (200 mmol L ${ }^{-1} \mathrm{NaOH}, 1 \mathrm{mmol} \mathrm{L}{ }^{-1}$ EDTA, $\left.\mathrm{pH}>13\right)$ and incubated at room temperature in the dark for $20 \mathrm{~min}$. After the unwinding step, electrophoresis was performed at $21 \mathrm{~V}$ for $30 \mathrm{~min}$. Slides were then rinsed with distilled water and fixed for $5 \mathrm{~min}$ in $70 \%$ ethanol. Slides were dried and stained for 5 min at $4{ }^{\circ} \mathrm{C}$ with SYBR Green I (Trevigen, Inc.,) diluted 1:10 000 in $10 \mathrm{mmol} \mathrm{L}^{-1}$ Tris $\mathrm{pH} 7.5$, $1 \mathrm{mmol} \mathrm{L}^{-1}$ EDTA, drained to remove excess staining solution and thoroughly dried at room temperature in the dark. 


\section{Results and discussion}

The complexes were synthesised as described in the Supporting Information (Scheme 1S). Phenanthroline-5-ethynylestradiol (A) is obtained using Sonogashira coupling reaction between 5-bromophenanthroline and ethynylestradiol (Scheme 1).

These kinds of reactions require extreme dry and degassed conditions and inert atmosphere; the reaction was optimized using milder conditions with respect to what was recently reported by us [41]. The yield and purity of the final product highly depend on the catalyst $\left[\mathrm{Pd}\left(\mathrm{PPh}_{3}\right)_{4}\right]$ which must be freshly prepared (See Supporting Information) and stored under argon at $-20^{\circ} \mathrm{C}$. Briefly, $\mathbf{A}$ is synthesised by coupling 5-bromophenanthroline and ethynylestradiol in dry THF with $3 \%$ of $\left[\mathrm{Pd}\left(\mathrm{PPh}_{3}\right)_{4}\right]$ as catalyst and diisopropylamine (DIPA) as a base. The replacement of $\mathrm{K}_{2} \mathrm{CO}_{3}$ with the DIPA for the base and of DMF with THF for the solvent, allowed the reaction to work at r.t. with the formation of less impurities. The reaction success is evident by the disappearance of the alkyne proton resonance at $2.6 \mathrm{ppm}$ in the ${ }^{1} \mathrm{H}-\mathrm{NMR}$ spectrum of A (Fig. 1S). Phenanthroline-5-ethynylestradiol (A), after purification, is mixed in a stoichiometric ratio $1: 1$ with the correspondent $\left[\mathrm{Cu}(\mathrm{N} \cap \mathrm{N})\left(\mathrm{OH}_{2}\right)_{2}\right]\left(\mathrm{NO}_{3}\right)_{2}(\mathbf{B}-\mathbf{E})$ (Scheme 1S), obtaining the final complexes 1-4 (Fig. 1, where $\mathrm{N} \cap \mathrm{N}=$ phen $-\mathbf{1} ; \mathrm{N} \cap \mathrm{N}=\mathrm{DPQ}-\mathbf{2} ; \mathrm{N} \cap \mathrm{N}=\mathrm{DPPZ}-\mathbf{3}$ and $\mathrm{N} \cap \mathrm{N}=\mathrm{DPPN}-\mathbf{4}$ ), as described in detail in the SI. The complexes 1-4, characterized with IR, El. analyses, mass spectrometry, were stable up to 1 week in saline solution $(0.9 \% \mathrm{NaCl})$. The electrochemical behavior of complexes 1-3 was investigated and Table 1 summarises the electrochemical data generated. All compounds exhibited a quasi-reversible wave when examined over the potential range 1 to $-1 \mathrm{~V}$, being ascribed to the $\mathrm{Cu}^{2+/ 1+}$ redox process (Fig. 1). No clear trend was evident with respect to $\mathrm{Cu}^{2+/ 1+} E_{1 / 2}$ values for the series $\mathbf{1 - 3}$, all of which fell within a similar interval $\left(-0.29\right.$ to $-0.27 \mathrm{~V}$ vs. $\left.\mathrm{Ag} / \mathrm{Ag}^{+}\right)$ that is within the biological range $(-0.2-0.4 \mathrm{~V})$ and they are likely to undergo reduction $\left(\mathrm{Cu}^{2+}+1 \mathrm{e}^{-} \rightarrow \mathrm{Cu}^{1+}\right)$ in physiological cell environment [43]. The relatively positive shift in all values for these complexes relative to that of the starting materials $\left.\left[\mathrm{Cu}(\mathrm{N} \cap \mathrm{N})\left(\mathrm{OH}_{2}\right)_{2}\right]\left(\mathrm{NO}_{3}\right)_{2}\right]$ B-D with $E_{1 / 2}$ values $-0.456 \mathrm{~V}$ (phen), $-0.363 \mathrm{~V}$ (DPQ) and $-0.311 \mathrm{~V}$ (DPPZ), may reflect the electron donating contribution of the estradiol conjugate and geometric alterations upon reduction of the $\mathrm{Cu}^{2+}$ centres in 1-3 to the $\mathrm{Cu}^{+}$ forms. Thus, the processes may be influenced by steric effects of the ligands which overshadow electronic effects $[44,45]$. The $\Delta E_{\mathrm{p}}$ values of the metal processes indicate a significant departure from a one electron reversible process, with the possibility of coupled chemical reactions and the geometric reorganisation which may accompany the $\mathrm{Cu}^{2+/ 1+}$ redox system. All $I_{\mathrm{p}(\mathrm{a})} / I_{\mathrm{p}(\mathrm{c})}$ ratios are close to unity for the diffusion-controlled metal process. When the cathodic limit was extended to $-2.0 \mathrm{~V}$ vs. $\mathrm{Ag} / \mathrm{Ag}^{+}$the metal underwent further one electron reduction $\mathrm{Cu}^{1+/ 0}$ with subsequent ligand dissociation and (in some cases) re-oxidation (stripping) of plated copper back to $\mathrm{Cu}^{+}$ upon anodic switching [45]. The quasi reversibility of the $\mathrm{Cu}^{2+/ 1+}$ metal processes (cathodic limit $-1 \mathrm{~V}$ vs. $\mathrm{Ag} / \mathrm{Ag}^{+}$) indicates little structural change prior to this point, after which it is likely that the complexes undergo decomposition. In the case of compounds $\mathbf{1}$ and $\mathbf{2}$, a significant anodic shift in the $E_{\mathrm{p}(\mathrm{c})}$ values for the phenanthroline and DPQ ligands was evident $(-1.99 \mathrm{~V}$ to $-1.3 \mathrm{~V}$ and $-1.92 \mathrm{~V}$ to $-1.37 \mathrm{~V}$, respectively). This may reflect a stabilisation of the LUMO state of the ligands, due in this case to the presence of the estradiol group, resulting in a more facile ligand reduction process. The electrochemical behaviour of natural and synthetic estrogens has been reported [46, 47] with ease of oxidation of the phenol group to the phenoxonium ion (a two electron process) being dependent on ring substitution and the solvent-electrolyte system. In these complexes, no estradiol anodic process is visible over the range examined, though clearly the presence of the steroid group influenced the phen, DPQ and DPPZ electrochemistry (Fig. 2; Table 1).
Scheme 1 Sonogashira coupling reaction for the synthesis of phenanthroline-5-ethynylestradiol A

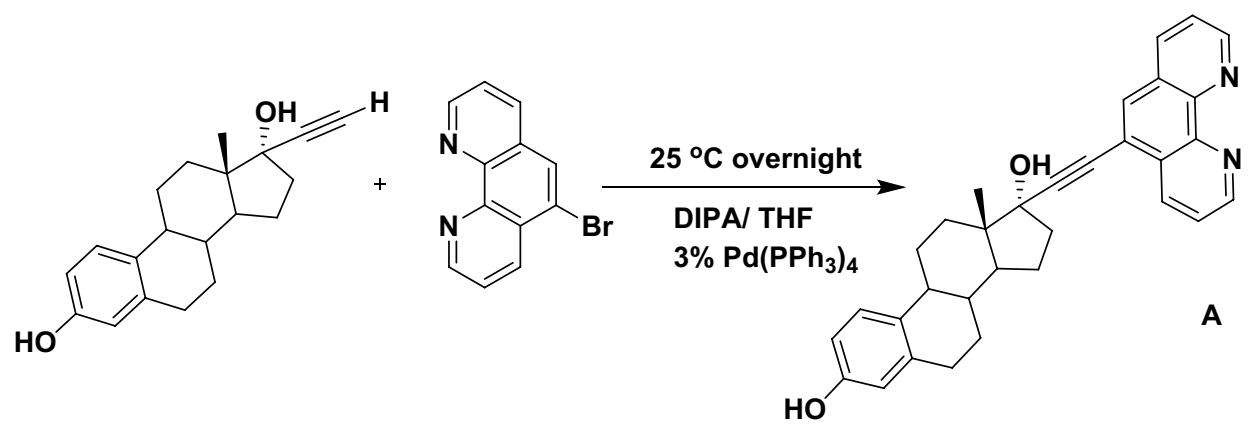




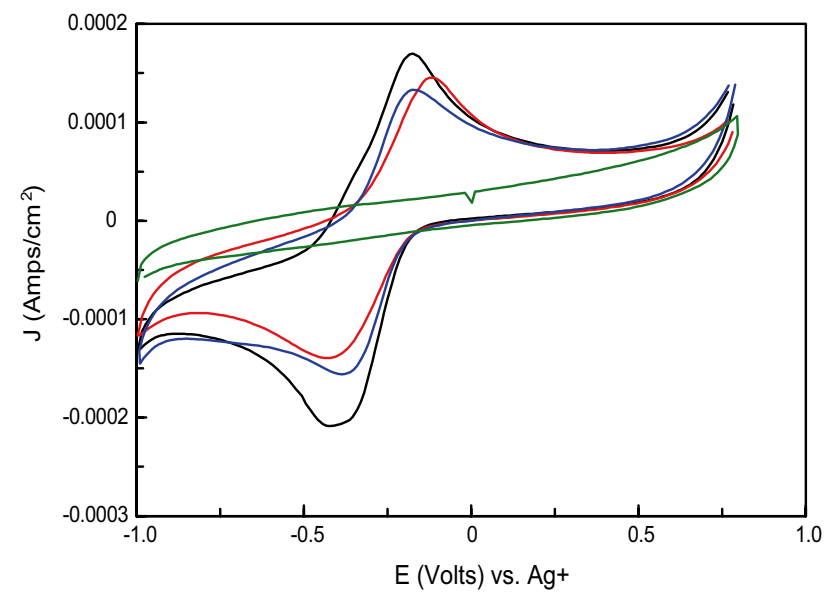

Fig. 2 Cyclic voltammogram of $1 \mathrm{mM}$ solution of complexes 1-3 at a glassy carbon electrode $\left(0.07 \mathrm{~cm}^{2}\right)$ in a three electrode configuration with $\mathrm{Pt}$ wire counter and non-aqueous reference $\mathrm{Ag} / \mathrm{Ag}^{+}$reference electrode in $0.1 \mathrm{M} \mathrm{LiClO}_{4} / \mathrm{DMF}$. Scan rate $100 \mathrm{mV} \mathrm{s}^{-1}$ over the potential range +1 to $-1 \mathrm{~V}$ vs. $\mathrm{Ag} / \mathrm{Ag}^{+}$. Background electrolyte (green circle), (1) (blue circle) (2) (red circle) (3) (black circle)

\section{Binding affinity to calf-thymus and salmon testes DNA}

The DNA binding affinity of the series of complexes was determined with calf-thymus and salmon testes duplex DNA polymers using a high throughput ethidium bromide and Hoechst 33258 fluorescence quenching assay [30], competition assay, and viscosity analyses (Fig. 3). The presence of modified phen ligands significantly enhanced the ctDNA binding affinity with $K_{\text {app }}$ (apparent DNA binding constant) values rising from $7 \times 10^{6} \mathrm{M}(\mathrm{bp})^{-1}$ for complex 1 (phen) to $\sim 10^{7} \mathrm{M}(\mathrm{bp})^{-1}$ for complexes 2 and $\mathbf{3}$ (DPQ and DPPZ, respectively). Both phenazine complexes had a binding affinity comparable to a reference intercalating antibiotic, Actinomycin D $\left(3 \times 10^{7} \mathrm{M}(\mathrm{bp})^{-1}\right)$ [28]. Complex 4, containing the extended phenazine substituent DPPN, had a lower binding constant of $\sim 5 \times 10^{6} \mathrm{M}(\mathrm{bp})^{-1}$ (Table 2), an effect previously observed with copper(II) ternary complexes [29]. Fluorescence quenching $(Q)$ of limited Hoechst 33258 (minor groove binder) and ethidium bromide (intercalator) bound ctDNA shows the complex series were not selective in displacing these fluorophores, however, a similar trend was observed in the displacement of both reporters: $\mathbf{3}>\mathbf{2}>\mathbf{1}>\mathbf{4}$ (Table 2 ). Viscosity analysis with salmon testes duplex DNA confirmed complex 3, containing the DPPZ ligand, as a strong intercalator and this hydrodynamic profile was followed by complex $\mathbf{2}$ (DPQ) and then 1 (phen, which presumably kinks DNA) [48]. Complex 4 with the larger DPPN ligand again displayed attenuated activity (Table 2). Moving from phen to DPQ and DPPZ the planarity and aromaticity of the ligands are optimized for DNA intercalation but the further modification to DPPN leads to steric hindrance thereby preventing efficient DNA binding [49, 50].

The DNA-cleavage ability of the $\mathrm{Cu}(\mathrm{II})$ complexes was measured by monitoring the conversion of SC-DNA (form I) to the nicked-circular form (NC, form II) using agarose gel electrophoresis (Fig. 4). SC pUC19 DNA (400 ng) was incubated with increasing complex concentrations (range $0.5-20 \mu \mathrm{M})$ in the presence of Na-L-ascorbate $(1 \mathrm{mM})$ for $3 \mathrm{~h}$. All complexes had the ability to convert SC-DNA into the nicked form at $1 \mu \mathrm{M}$ but complex 3 , the DPPZ-containing complex, displayed the highest cleavage potency being able to cleave plasmid DNA already at $0.5 \mu \mathrm{M}$ concentration. In absence of Na-L-ascorbate no detectable cleavage was observed.

With the aim of evaluating the antitumor potential of the newly developed $\mathrm{Cu}$ (II) complexes $\mathbf{1 - 4}$, and to verify if they are more effective in targeting ER+cell lines with respect to ER- ones, their in vitro antitumor potential was assessed in a panel of ER+human cancer cell lines, A431 (cervical), MCF-7 (breast), 2008 (ovarian) and A2780 (ovarian) cancer cells as well as against ER- HCT15 colon cancer cells. Cells were exposed to the tested compounds for $72 \mathrm{~h}$ and the $\mathrm{IC}_{50}$ values, calculated from the dose-response curves, are reported in Table 3 . The stability of complex 4 in phosphate buffer solution $\left(37^{\circ} \mathrm{C}\right.$, $\mathrm{pH}$ 7.4) was previously evaluated via HPLC to confirm that the estrogen moiety, that can be carcinogenic being a steroid, is not released from the coordination sphere of the metal centre. Figure $3 \mathrm{~S}$ reports the chromatograms
Table 1 Electrochemical data for complexes 1-3

\begin{tabular}{|c|c|c|c|c|c|c|c|c|c|}
\hline \multirow[t]{2}{*}{ Complex } & \multirow{2}{*}{$\begin{array}{l}\text { Cathodic } \\
\text { limit (V) }\end{array}$} & \multicolumn{3}{|l|}{$\mathrm{Cu}(\mathrm{I} / \mathrm{II})$} & \multirow{2}{*}{$\begin{array}{l}\mathrm{Cu}(0 / \mathrm{I}) \\
E_{\mathrm{p}(\mathrm{c})}(\mathrm{V})\end{array}$} & \multicolumn{4}{|c|}{ Ligand redox process } \\
\hline & & $E_{1 / 2}(\mathrm{~V})$ & $\Delta E_{\mathrm{p}}(\mathrm{V})$ & $I_{\mathrm{p}(\mathrm{a})} / I_{\mathrm{p}(\mathrm{c})}$ & & $E_{\mathrm{p}(\mathrm{a})}(\mathrm{V})$ & $E_{\mathrm{p}(\mathrm{c})}(\mathrm{V})$ & $E_{1 / 2}(\mathrm{~V})$ & $\Delta E_{\mathrm{p}}(\mathrm{V})$ \\
\hline \multirow[t]{2}{*}{1} & -1 & -0.2769 & 0.198 & 0.85 & - & - & - & - & - \\
\hline & -2 & - & - & - & - & - & -1.3 & - & - \\
\hline \multirow[t]{2}{*}{2} & -1 & -0.272 & 0.296 & 1 & - & - & - & - & - \\
\hline & -2 & - & - & - & - & - & -1.37 & - & - \\
\hline \multirow[t]{3}{*}{3} & -1 & -0.287 & 0.225 & 0.84 & - & - & - & - & - \\
\hline & -2 & & & & -1.17 & -1.365 & -1.475 & -1.42 & 0.11 \\
\hline & -2 & & & & & & -1.845 & & \\
\hline
\end{tabular}




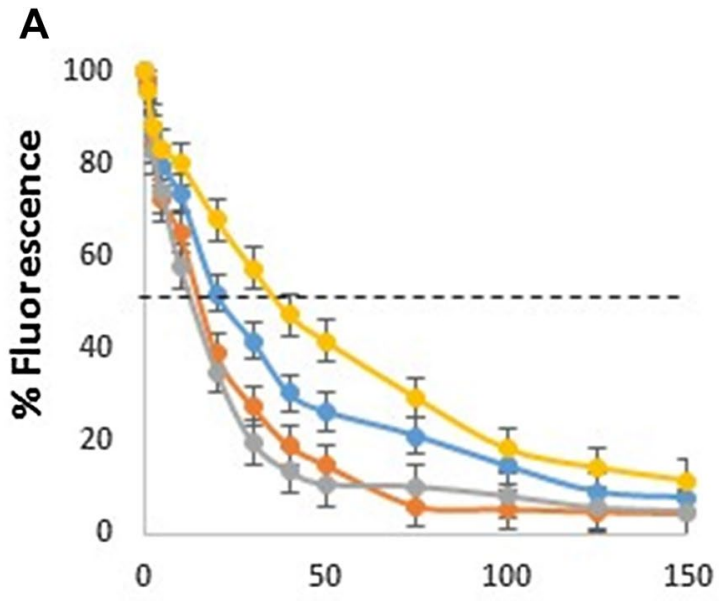

Drug concentration $\mu \mathrm{M}$

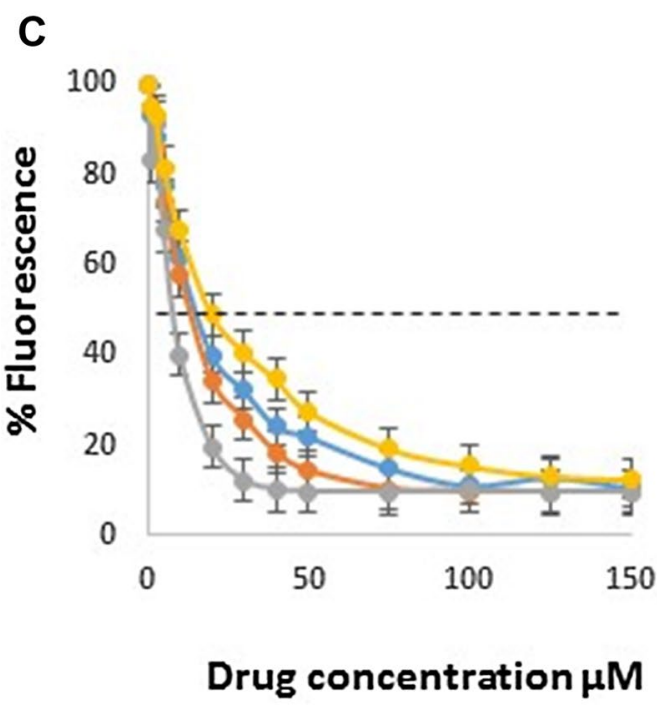

Fig. 3 Binding of complexes 1 (blue circle), 2 (orange circle), 3 (gray circle), and $\mathbf{4}$ (yellow circle) to A ethidium bromide saturated solution of dsDNA (ctDNA); $\mathbf{B}$ and $\mathbf{C}$ fluorescence quenching of limited

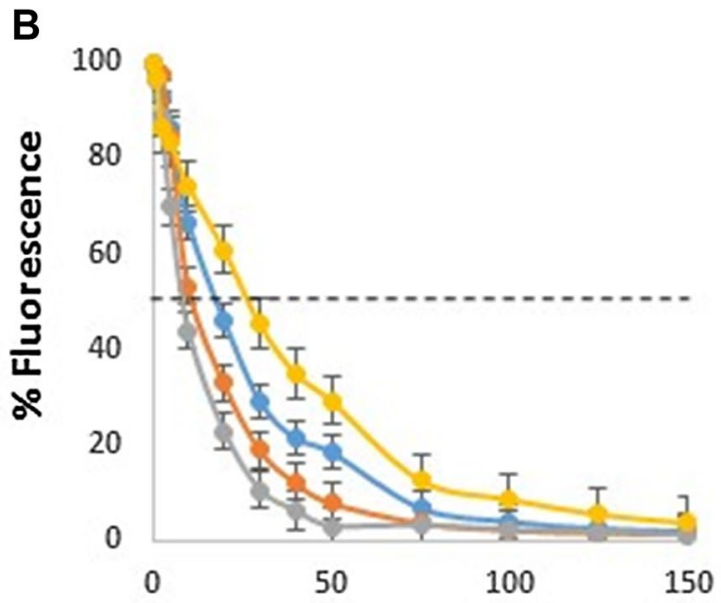

Drug concentration $\mu \mathrm{M}$

D

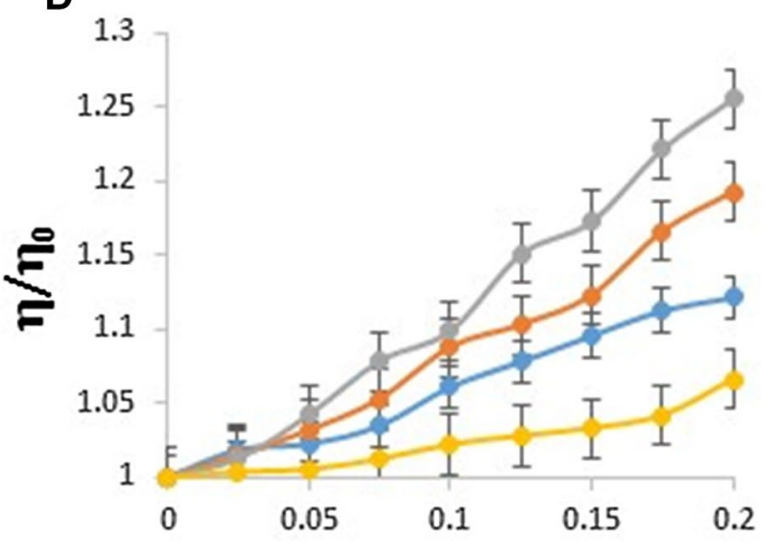

R [drug]/[DNA]

ethidium bromide or Hoechst 33258 bound ds DNA (ctDNA) upon titration of complexes; D viscosity properties of complex treated salmon testes dsDNA
Table 2 DNA binding properties of complexes 1-4

\begin{tabular}{lcllll}
\hline Complex & $C_{50}(\mu \mathrm{M})^{\mathrm{a}}$ & $K_{\text {app }} \mathrm{M}\left(\mathrm{bp}^{-1}\right)^{\mathrm{b}}$ & $Q(\mathrm{EtBr}, \mu \mathrm{M})^{\mathrm{c}}$ & $\begin{array}{l}Q(\text { Hoechst, } \\
\mu \mathrm{M})^{\mathrm{c}}\end{array}$ & $n / n_{0}(r=0.2)^{\mathrm{d}}$ \\
\hline $\mathbf{1}$ & 16.13 & $7.21 \times 10^{6}$ & 21.5 & 16.4 & 1.12 \\
$\mathbf{2}$ & 12.70 & $9.43 \times 10^{6}$ & 15.1 & 12.9 & 1.19 \\
$\mathbf{3}$ & 8.32 & $1.44 \times 10^{7}$ & 12.5 & 9.29 & 1.25 \\
$\mathbf{4}$ & 21.50 & $5.57 \times 10^{6}$ & 37.6 & 26.1 & 1.06 \\
\hline
\end{tabular}

${ }^{\mathrm{a}} C_{50}=$ concentration required to reduce fluorescence by $50 \%$

${ }^{\mathrm{b}} K_{\text {app }}=K_{\mathrm{e}} \times 12.6 / \mathrm{C}_{50}$ where $K_{\mathrm{e}}=9.5 \times 10^{6} \mathrm{M}\left(\mathrm{bp}^{-1}\right)$

${ }^{\mathrm{c}}$ Reduction of $50 \%$ initial fluorescence from DNA-bound dye by tested compound $(\mu \mathrm{M})$

${ }^{\mathrm{d}}$ Relative viscosity value at $r=0.20$ 
Fig. 4 DNA cleavage. Agarose gel electrophoresis patterns of SC pUC19 DNA incubated with complexes 1-4 $(0.5-20 \mu \mathrm{M})$ in HEPES buffer at $37^{\circ} \mathrm{C}$ for $3 \mathrm{~h}$

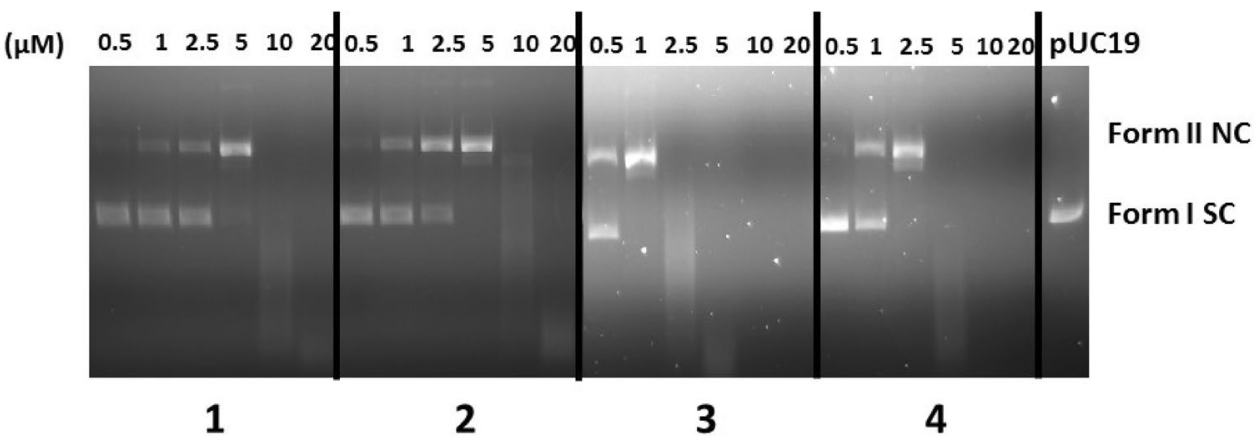

Table 3 In vitro cytotoxic activity of complexes 1-4

\begin{tabular}{lcllll}
\hline \multicolumn{5}{l}{$\mathrm{IC}_{50}(\mu \mathrm{M}) \pm \mathrm{SD}$} \\
\cline { 2 - 6 } & $\mathrm{A} 2780$ & 2008 & \multicolumn{1}{l}{ A431 } & MCF-7 & HCT-15 \\
\hline $\mathbf{1}$ & $0.6 \pm 0.1$ & $1.5 \pm 0.7$ & $1.3 \pm 0.3$ & $1.0 \pm 0.2$ & $0.8 \pm 0.3$ \\
$\mathbf{2}$ & $0.3 \pm 0.02$ & $1.6 \pm 0.4$ & $2.0 \pm 0.4$ & $1.2 \pm 0.3$ & $0.8 \pm 0.1$ \\
$\mathbf{3}$ & $0.1 \pm 0.04$ & $0.2 \pm 0.1$ & $0.1 \pm 0.1$ & $0.7 \pm 0.2$ & $0.5 \pm 0.2$ \\
$\mathbf{4}$ & $0.04 \pm 0.01$ & $0.6 \pm 0.03$ & $0.3 \pm 0.03$ & $0.9 \pm 0.2$ & $0.5 \pm 0.2$ \\
Cisplatin & $2.6 \pm 0.8$ & $2.2 \pm 0.6$ & $1.7 \pm 0.3$ & $7.6 \pm 0.2$ & $13.9 \pm 1.7$ \\
\hline
\end{tabular}

Cells $\left(3-8 \times 10^{3} \mathrm{~mL}^{-1}\right)$ were treated for $72 \mathrm{~h}$ with increasing concentrations of the tested compounds. Cytotoxicity is assessed by MTT test. $\mathrm{IC}_{50}$ values $(\mu \mathrm{M})$ were calculated by a four parameter logistic model $(p<0.05)$

$S D$ standard deviation

of 4 immediately upon dissolution and after $72 \mathrm{~h}$ where it is clearly visible that the complex is highly stable with negligible amount of steroid released.

All the complexes promoted a significant cytotoxic activity, with $\mathrm{IC}_{50}$ values in the low-/sub-micromolar range against all cancer cell lines tested. In general, all derivatives were more effective in inducing cancer cell death with respect to the reference metallodrug cisplatin. Among the newly developed $\mathrm{Cu}(\mathrm{II})$ compounds, 3 and $\mathbf{4}$ were the most potent derivatives, with $\mathrm{IC}_{50}$ calculated towards all tested cancer cells in the sub-micromolar range. These data indicate that by increasing the lipophilicity of the diamine ligand in turn increased the cytotoxic activity of the related copper(II) complex. On the other hand, complexes 1-3 displayed equally cytotoxic properties against ER+ and ER- cancer cells, thus suggesting the inability of these complexes to selectively target ER+ cancer cells. Conversely, 4 proved to be slightly more effective against ER+ A2780 ovarian cancer cells.

The in vitro antitumor potential of the $\mathrm{Cu}$ (II) complexes was also examined in 3D cell culture models of ovarian $(\mathrm{ER}+)$ and colon (ER-) cancers. Actually, even if the 2D cell cultures is the most used in vitro method for screening of potential therapeutics due to its simplicity, reproducibility, and low cost, this method is unable to reproduce the
Table 4 In vitro cytotoxicity against ovarian and colon cancer cell spheroids

\begin{tabular}{lcr}
\hline & \multicolumn{1}{c}{$\mathrm{IC}_{50}(\mu \mathrm{M}) \pm \mathrm{SD}$} & \multicolumn{1}{c}{$\mathrm{HCT} 15$} \\
\cline { 2 - 3 } & $\mathrm{A} 2780$ & $7.7 \pm 1.6$ \\
$\mathbf{1}$ & $10.6 \pm 1.0$ & $9.9 \pm 1.0$ \\
$\mathbf{3}$ & $7.7 \pm 1.0$ & $9.2 \pm 0.6$ \\
$\mathbf{4}$ & $4.1 \pm 0.1$ & $8.6 \pm 0.5$ \\
Cisplatin & $3.0 \pm 0.02$ & $68.3 \pm 2.1$ \\
\hline
\end{tabular}

Spheroids $\left(1.5 \times 10^{3}\right.$ cells/well) are treated for $72 \mathrm{~h}$ with increasing concentrations of test compounds. The growth inhibitory effect was evaluated by means of the $\mathrm{APH}$ test. $\mathrm{IC}_{50}$ values were calculated from the dose-survival curves by the four parameter logistic model $(p<0.05)$

SD standard deviation

properties of in vivo solid tumors. 3D cell cultures, possessing several features that more closely mimic the heterogeneity and complexity of in vivo tumors, are recognized to be more predictive for in vivo results than conventional 2D cell cultures [51]. The cancer spheroids were treated with copper(II) complexes or cisplatin for $72 \mathrm{~h}$ and cell viability was assessed by means of the acid phosphatase (APH) assay (Table 4).

These tested non-proliferative and very resistant tumour models, 1-4 were extremely effective, being more active than cisplatin against both A2780 ovarian and HCT-15 colon cancer cell spheroids. In particular, $\mathbf{3}$ and $\mathbf{4}$ were confirmed as the most potent derivatives, being about 30 and 9 times more effective than cisplatin in A2780 and HCT-15 3D cell cultures, respectively.

Complexes 1-3 showed a similar activity toward ER+ and ER- cancer cells, thus confirming the results obtained in the 2D system and supporting the hypothesis of their inability to selectively target ER+ cancer cells. On the contrary, in 3D systems, compound $\mathbf{4}$ again showed a certain degree of selectivity towards A2780 cancer cells, being about 3 times more effective in ER+human ovarian cancer cells with respect to ER- human colon cancer cells. With the aim of identifying a possible correlation between cytotoxic 
A

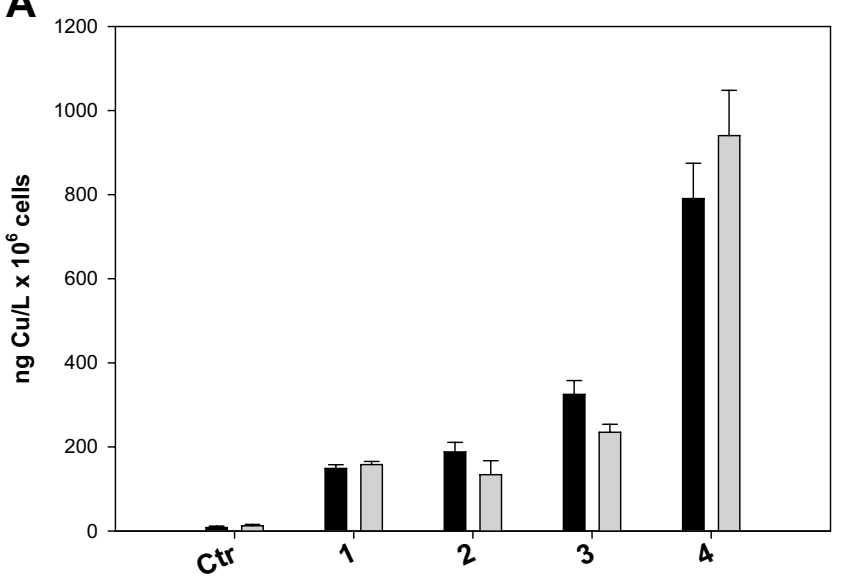

Fig. 5 Cellular uptake in A2780 (grey bars) and HCT-15 (black bars) cancer cells. A Cancer cells were incubated with $0.5 \mu \mathrm{M}$ of copper complexes for $24 \mathrm{~h}$, and cellular copper content was detected by GF-

activity and cellular accumulation, cellular copper content was measured in ER+A2780 and ER- HCT-15 cancer cells treated for $24 \mathrm{~h}$ with equimolar concentrations of the tested compounds. The cellular copper levels were quantified by means of GF-AAS analysis, and the results, expressed as ng $\mathrm{Cu}$ per $10^{6}$ cells, are shown in Fig. 5A.

Although to a different extent, all derivatives were able to cross the cancer cell membrane and enter cancer cells. Complexes 1-3 were able to similarly accumulate into ovarian and colon cancer cells, whereas derivative $\mathbf{4}$ was significantly more effective in entering ER+A2780 cancer cells. Interestingly, 4 accumulated in a time-dependent manner, actually both ovarian and colon cancer cells displayed a time-dependent increase in cellular copper content (Fig. 5B). By matching cytotoxic activity data with those arising from cellular uptake quantification, a linear and direct correlation is evidenced (Fig. 4S).

Copper species have been regarded as redox active compounds and it was shown that copper complexes may catalyze the reaction of hydrogen peroxide in the form of Fenton-like reactions inside the cell to produce ROS, thus altering cellular redox homeostasis and driving cells towards oxidative stress. On these bases, we evaluated cellular ROS levels in A2780 cells treated with $10 \mu \mathrm{M}$ of the most effective complex 4. ROS production was monitored using the peroxide-sensitive fluorescent probe CM- $\mathrm{H}_{2}$ DCFDA [5-(and-6)-chloromethyl-2', 7'-dichlorodihydrofluorescein diacetate, acetyl ester]. Antimycin, a classical inhibitor of the mitochondrial respiratory chain at the level of complex III, was used as a positive control.

The results, expressed as arbitrary units of fluorescence as a function of time, are shown in Fig. 6A. Interestingly, 4 was able to substantially stimulate the production of hydrogen peroxide in a time-dependent manner, to a rather
B

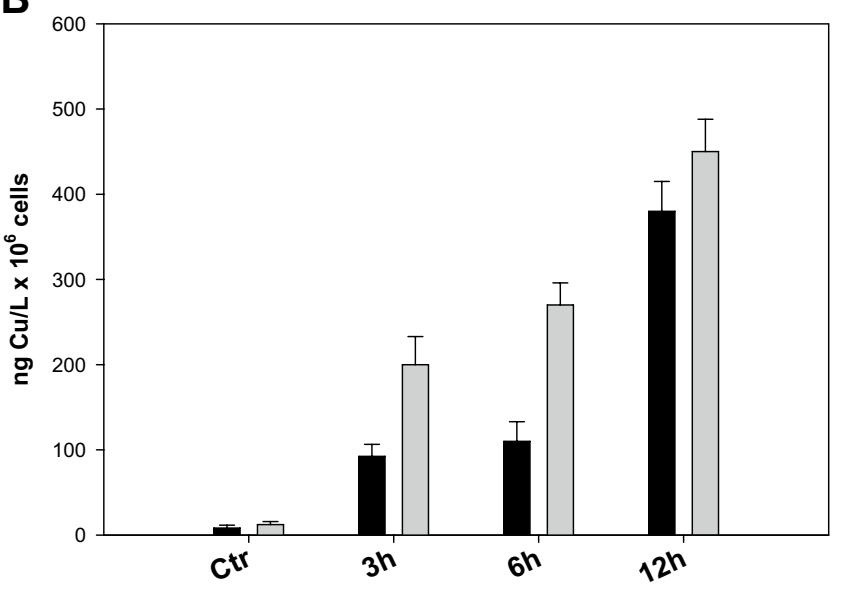

AAS analysis. B Cancer cells were incubated with $0.5 \mu \mathrm{M}$ of copper complex 4 for 3, 6 or $12 \mathrm{~h}$, and cellular copper content was detected by GF-AAS analysis. Error bars indicate the standard deviation

similar extent as the respiratory chain complex III inhibitor, antimycin.

In addition, we confirmed the results obtained in cellfree experiments (DNA binding, cleavage and viscosimetry studies) and we assessed the ability of the newly synthesised copper(II) complexes to bind and to damage the DNA within intact cancer cells. The DNA damage in A2780 cells was studied after treatment with $\mathbf{4}$ for $3 \mathrm{~h}$, using alkaline single cell gel electrophoresis (Comet assay, Fig. 6B). The results were compared with those obtained after treatment of A2780 cells with equitoxic concentrations of dichloro(1,10-phenanthroline)copper(II), [Cu(phen)]. Similar to [Cu(phen)], the 4-treated cells displayed a statistically significant increase in electrophoretic migration of the DNA fragments, evidenced by well-formed comets. To analyze the cellular DNA binding, cells A2780 were treated with complexes 1-4 for $24 \mathrm{~h}$, as described in the experimental section, and the amount of copper covalently bound to the extracted DNA was determined via GF-AAS. All the complexes showed very little capacity to bind to the DNA in a covalent mode comparison to the endogenous $\mathrm{Cu}$ control (Fig. 5S), confirming that the interaction between the complexes and DNA is purely electrostatic (intercalation).

These results confirmed the ability of these copper(II) complexes to target DNA in intact cancer cells.

\section{Conclusions}

Four copper(II)-based complexes containing the female steroid estradiol, were synthesised with the aim to selectively target cancer cells overexpressing the estrogen receptors. The complexes proved to be very effective against all 
A

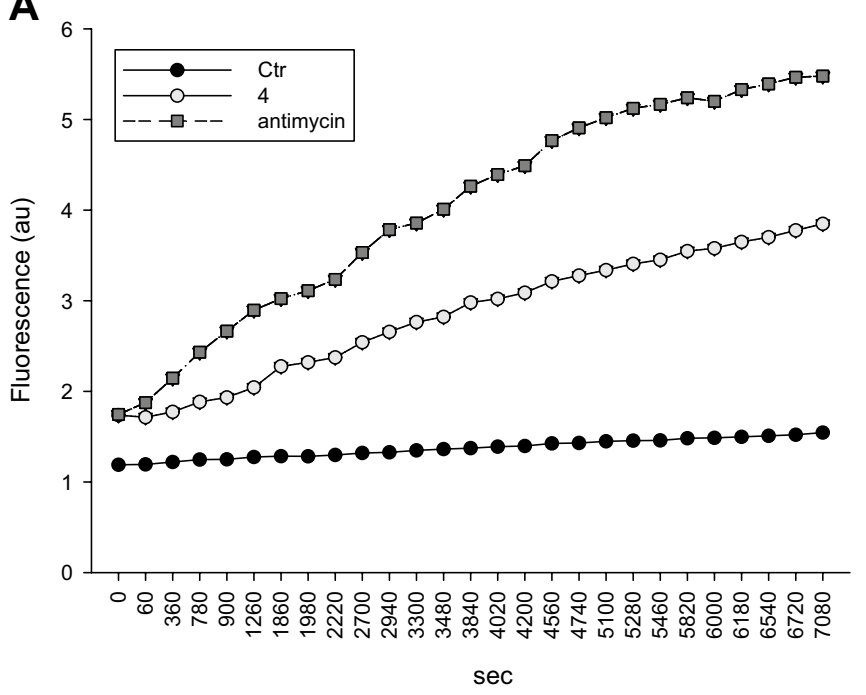

B

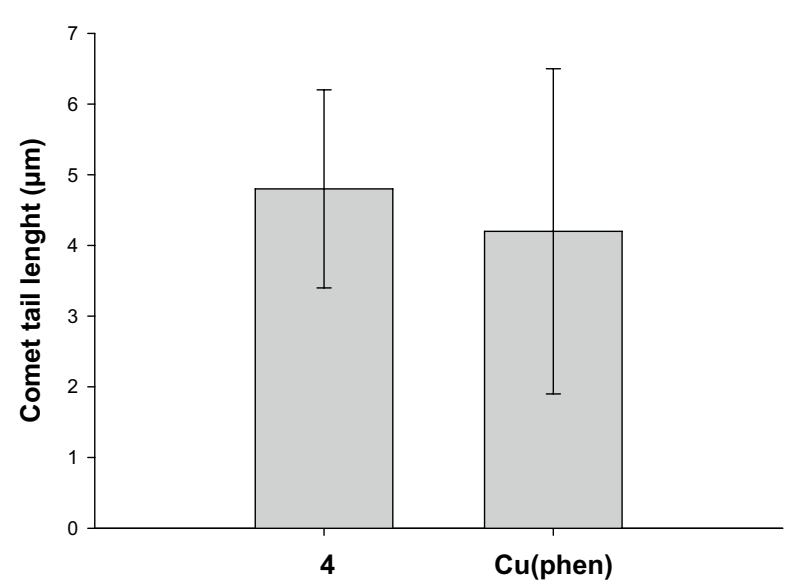

Fig. 6 Mechanistic studies: ROS production (a) and DNA damage (b) in A2780 cancer cells. A Cells were preincubated in PBS/10 mM glucose medium for $20 \mathrm{~min}$ at $37{ }^{\circ} \mathrm{C}$ in the presence of $10 \mu \mathrm{M} \mathrm{CM}$ DCFDA and then treated with derivative $4(10 \mu \mathrm{M})$ or antimycin $(3 \mu \mathrm{M})$. The fluorescence of DCF was measured as reported in the

the cancer cell lines examined (low and sub $\mu \mathrm{M} \mathrm{IC}_{50}$ values), much more with respect to the reference drug cisplatin, complex 4 being the most effective one. Although no selectivity was observed for ER+ with respect to ER - cells for complexes 1-3, for complex $\mathbf{4}$ a slight difference in anticancer potential towards ER+ cancer cells was underlined. Actually, a linear correlation was obtained in ER+cancer cells between drug uptake and $\mathrm{IC}_{50}$ values. In general, the antiproliferative activity and cellular uptake increased with the lipophilic character of $\mathrm{Cu}$ (II) complexes, thus indicating that cellular internalisation is principally due to a passive diffusion mechanism with a minimum role of the estrogen moiety. From a mechanistic point of view, cell-free fluorescent analyses evidenced for all copper complexes strong intercalation properties but a discrimination between major and minor groove was not observed. $\mathrm{Cu}(\mathrm{II})$ complexes were redox active at the physiological range and were able to cleave DNA at very low concentrations $(0.5 \mu \mathrm{M})$ in the presence of a reducing agent. More interestingly, cell studies confirmed their ability to target DNA and to induce ROS production in ER+ human cancer cells.

Acknowledgements SB is grateful to the Department of Chemistry of Maynooth University for sponsoring the postgrad scholarship. Maynooth University, Dublin City University, NUIG, University of Padova, the Italian Ministero dell'Università e della Ricerca (MIUR), and the Inter-University Consortium for Research on the Chemistry of Metal Ions in Biological Systems (CIRCMSB) are gratefully acknowledged. experimental section. B A2780 cells were treated for $3 \mathrm{~h}$ with $0.5 \mu \mathrm{M}$ of compound $\mathbf{4}$ and then processed for the comet assay as reported in the experimental section. Comet tail length was calculated from the center of the cell and measured in micrometers with ImageJ software. The error bars indicate the standard deviation

\section{Compliance with ethical standards}

Conflict of interest There are no conflicts to declare.

\section{References}

1. Santini C, Pellei M, Gandin V, Porchia G, Tisato F, Marzano C (2014) Chem Rev 114:815-862

2. Kellett A, Molphy Z, McKee V, Slator C (2019) Recent advances in anticancer copper compounds. In: Casini A, Vessieres A, Meier-Menches SM (eds) Chapter 4, Metal based anticancer agents. The Royal Society of Chemistry, pp 91-119. https://doi. org/10.1039/9781788016452-00091

3. Trejo-Solis C, Jimenez-Farfan D, Rodriguez-Enriquez S, Fernando-Valverse F, Cruz-Salgado A, Ruiz-Azuare L, Sotelo J (2012) BMC Cancer 12:156

4. Silva-Platas C, Villegas CA, Oropeza-Almazán Y, Carrancá M, Torres-Quintanilla A, Lozano O, Valero-Elizondo J, Castillo EC, Bernal-Ramírez J, Fernández-Sada E, Vega LF, Treviño-Saldaña N, Chapoy-Villanueva H, Ruiz-Azuara L, Hernández-Brenes C, Elizondo-Montemayor L, Guerrero-Beltrán CE, Carvajal K, Bravo-Gómez ME, García-Rivas G (2018) Oxid Med Cell Longev. https://doi.org/10.1155/2018/8949450 (ID 8949450)

5. Ming LJ (2003) Med Res Rev 23:697-762

6. Yu Y, Kalinowski DS, Kovacevic Z, Siafakas AR, Jansson PJ, Stefani C, Lovejoy DB, Sharpe PC, Bernhardt PV, Richardson DR (2009) J Med Chem 52:5271-5294

7. Chen D, Peng F, Cui QC, Daniel KG, Orlu S, Liu J, Dou QP (2005) Front Biosci 10:2932-2939

8. Chen ZF, Tan MX, Liu LM, Liu YC, Wang HS, Yang B, Peng Y, Liu HG, Liang H, Orvig C (2009) Dalton Trans 48:10824-10833 
9. Laws K, Binjeva-Todd G, Eskandari A, Lu C, O'Reilly N, Suntharalingam K (2018) Angew Chem Int Ed 57:287-291

10. Lu C, Laws K, Eskandari A, Suntharalingam K (2017) Dalton Trans 46:12785-12789

11. Balzarini J, Keyaerts E, Vijgen L, Vandermeer F, Stevens M, De Clercq E, Egberink H, Van Ranst M (2006) J Antimicrob Chemother 57:472-481

12. Kellett A, Molphy Z, Slator C, McKee V, Farrell NP (2019) Chem Soc Rev 48:971-988

13. Molphy Z, Montagner D, Bhat SS, Slator C, Long C, Erxleben A, Kellett A (2018) Nucleic Acid Res 46:9918-9931

14. Fleming AM, Muller JG, Li L, Burrows CJ (2011) Org Biomol Chem 9:3338-3348

15. Buchtik R, Travnicek Z, Vanco J (2012) J Inorg Biochem 116:163-171

16. Montagner D, Gandin V, Marzano C, Erxleben A (2015) Inorg Chim Acta 145:101-107

17. Jopp M, Becker J, Becker S, Miska A, Gandin V, Marzano C, Schindler S (2017) Eur J Med Chem 132:274-281

18. Slator C, Molphy Z, McKee V, Long C, Brown T, Kellett A (2018) Nucleic Acid Res 46:2733-2750

19. Müller S, Versini A, Sindikubwabo F, Belthier G, Niyomchon S, Pannequin J, Grimaud L, Cañeque T, Rodriguez R (2018) PLoS One 13:e0208213

20. Zuin Fantoni N, Molphy Z, Slator C, Menounou G, Toniolo G, Mitrikas G, McKee V, Chatgilialoglu C, Kellett A (2019) Chem Eur J 25:221-237

21. Sigman DS, Zelenko O, Gallagher J, Xu Y (1998) Inorg Chem 37:2198-2204

22. Meijler MM, Zelenko O, Sigman DS (1997) J Am Chem Soc 119:1135-1136

23. Zhou H, Zheng C, Zou G, Tao J (2002) Gong D. Int J Biochem Cell Biol 34:678-684

24. Pitie M, Donnadieu B, Meunier B (1998) Inorg Chem 37:3486-3489

25. Trejo-Solís C, Jimenez-Farfan D, Rodriguez-Enriquez S, Fernandez-Valverde F, Cruz-Salgado A, Ruiz-Azuara R, Sotelo J (2012) BMC Cancer 12:1471-2407

26. Thomas AM, Nethaji M, Mahadevan S, Chakravarty AR (2003) J Inorg Biochem 94:171-178

27. Charefa F, Sebtia N, Arrara L, Djarmounia M, Boussoualima N, Baghiania A, Khennoufb S, Damend SAL, Mubarakd MS, Peterse DG (2015) Polyhedron 85:450-456

28. Tummalapalli K, Vasavi CS, Munusami P, Pathak M, Balamurali MM (2017) Int J Biol Macromol 95:1254-1266

29. Molphy Z, Prisecaru A, Sleitor C, Barron N, McCann M, Colleran J, Chandran D, Gathergood N, Kellett A (2014) Inorg Chem 53:5392-5404

30. McCann M, McGinley J, Ni K, O’Connor M, Kavanagh K, McKee V, Colleran J, Deveraux M, Gathergood N, Barron N, Prisecaru A, Kellett A (2013) Chem Commun 49:2431-2433
31. Le Bideau F, Dagorne S (2013) Chem Rev 113:1193-7850

32. Provencher-Mandeville J, Descoteaux C, Mandal SK, Leblanc V, Asselin E, Berube G (2008) Bioorg Med Chem Lett 18:2282-2287

33. Provencher-Mandeville J, Debnath C, Mandal SK, Leblanc V, Parent S, Asselin E, Berube G (2011) Steroids 76:94-103

34. Sanchez-Cano C, Huxley M, Ducani C, Hamad AE, Browning M, Navarro-Ranninger C, Quiroga AG, Rodger A, Hannon MJ (2010) Dalton Trans 39:11365-11374

35. Huxley M, Sanchez-Cano C, Browning MJ, Navarro-Ranninger C, Quiroga AG, Rodger A, Hannon MJ (2010) Dalton Trans 39:11353-11364

36. Altman J, Castrillo T, Beck W, Bernhardt G, Schoenenberger H (1991) Inorg Chem 30:4085-4088

37. Kenny RG, Marmion CJ (2019) Chem Rev 119:1058-1137

38. Saha P, Descôteaux C, Brasseur K, Fortin S, Leblanc V, Parent S, Asselin E, Bérubé G (2012) Eur J Med Chem 48:385-390

39. Linden HM, Peterson LM, Fowler AM (2018) PET Clin 13:415-422

40. Velle A, Maguire R, Kavanagh K, Montagner D, Sanz-Miguel PJ (2017) ChemMedChem 12:841-844

41. Barrett S, Delaney S, Kavanagh K, Montagner D (2018) Inorg Chim Acta 479:261-265

42. Kitteringham E, Andriollo E, Gandin V, Montagner D, Griffith D (2019) Inorg Chim Acta 495:118944. https://doi.org/10.1016/j. ica.2019.05.043

43. Zheng P, Eskandari A, Lu C, Laws K, Aldous L, Suntharalingam K (2019) Dalton Trans 48:5892-5896

44. Magni M, Colomba A, Dragonetti C, Mussini P (2014) Electrochim Acta 141:324-330

45. Justin Thomas KR, Tharmaraj P, Chandrasekhar V, Bryan D, Cordes AW (1994) Inorg Chem 33:5382-5390

46. Mitrofanov M, Manowong M, Rousselin Y, Brandes S, Guilard R, Bessmertbykh-Lemeume A, Chen P, Kadish KM, Goulioukina N, Beletskaya I (2014) Eur J Inorg Chem 2014:3370-3386

47. Ngundi MN, Sadik OA, Yamaguchi T, Suye SI (2003) Electrochem Commun 5:61-67

48. Niyazi H, Hall JP, O’Sullivan K, Winter G, Sorensen T, Kelly JM, Cardin CJ (2012) Nat Chem 4:621-628

49. McGivern TJP, Slator C, Kellett A, Marmion CJ (2018) Mol Pharm 15:5058-5071

50. Ude Z, Kavanagh K, Twamley B, Pour M, Gathergood N, Kellett A, Mamion CJ (2019) Dalton Trans 48:8578-8593

51. Kunz-Schughart LA, Freyer JP, Hofstaedter F, Ebner R (2004) J Biomol Screen 9:273-282

Publisher's Note Springer Nature remains neutral with regard to jurisdictional claims in published maps and institutional affiliations.

\section{Affiliations}

\section{Stephen Barrett ${ }^{1} \cdot$ Michele De Franco $^{2} \cdot$ Andrew Kellett $^{3} \cdot$ Eithne Dempsey $^{1} \cdot$ Cristina Marzano $^{2} \cdot$ Andrea Erxleben $^{4}$. Valentina Gandin ${ }^{2}$. Diego Montagner ${ }^{1}$ (D)}

1 Department of Chemistry, Maynooth University, Maynooth, Ireland

2 Department of Pharmaceutical and Pharmacological Sciences, University of Padova, Padua, Italy
3 School of Chemical Sciences and National Institute for Cellular Biotechnology, Dublin City University, Glasnevin, Dublin 9, Ireland

4 School of Chemistry, National University of Ireland Galway, Galway, Ireland 